\begin{tabular}{|l|l|}
\hline $\begin{array}{l}\text { ESCOLA DE COMUNICAÇÃO, } \\
\text { ARTES E DESIGN }\end{array}$ & $\begin{array}{l}\text { mídia, cultura e tecnologia } \\
\text { Pevista FAMECOS, Porto Alegre, v. 27, p. 1-18, jan.-dez. } 2020 \\
\text { PUCRS } \\
\text { FAMECOS } \\
\text { e-ISSN: 1980-3729 | ISSN-L: 1415-0549 }\end{array}$ \\
\hline https://dx.doi.org/10.15448/1980-3729.2020.1.36731
\end{tabular}

MÍDIA E CULTURA

\title{
Representação do punk rock paulista em capas de disco
}

\author{
Representation of punk rock from São Paulo of long playing album covers
}

Representación del punk rock paulista en portadas de discos

\author{
Herom Vargas ${ }^{1}$ \\ 0000-0002-7837-6740 \\ heromvargas50@gmail.com

\section{Renan Marchesini de \\ Quadros Souza ${ }^{1}$ \\ 0000-0002-7607-8870} \\ marchesinirenan@gmail.com
}

Recebido em: 30/12/2019.

Aprovado em: 7/11/2020.

Publicado em: 22/12/2020.
Resumo: A proposta deste artigo é analisar as formas de representação do punk rock de São Paulo e da região do ABC paulista nas imagens das capas de discos long playing (LP). As noções de representação e cultura, a partir de Stuart Hall (2016), e texto cultural e semiosfera, de luri Lotman (1996), serão as bases para o entendimento da capa enquanto elemento cultural de mediação. 26 discos compõem o corpus analisado, sendo três coletâneas seminais do movimento e 23 lançados por sete bandas paulistas importantes na década de 1980 e início de 1990: Cólera, Garotos Podres, Inocentes, Mercenárias, Olho Seco, Ratos de Porão e Restos de Nada. As representações ocorrem em imagens figurativas e abstratas de quatro maneiras básicas: colagem e estética "suja"; figuração do personagem punk; imagens de violência, abjeção e tensão; críticas ao capitalismo e à sociedade de consumo.

Palavras-chave: Punk rock. Capa de disco. Representação.

Abstract: The aim of this article is to analyze the forms of representation of punk rock from São Paulo and ABC Paulista region in the images of long playing album covers. The notions of representation and culture, from Stuart Hall (2016) and cultural and semiosphere text, from luri Lotman (1996), will be the basis for understanding the cover as a cultural element of mediation. 26 records compose the analyzed corpus, with three seminal collections of the movement and 23 released by seven important São Paulo bands in the 1980s and early 1990s: Cólera, Garotos Podres, Inocentes, Mercenárias, Olho Seco, Ratos de Porão and Restos de Nada. The representations occur in figurative and abstract images in four primary ways: collage and "dirty" aesthetics; figuration of the punk character; images of violence, abjection and tension; criticisms of capitalism and the consumer society

Keywords: Punk rock. Album cover. Representation.

Resumen: El propósito de este artículo es analizar las formas de representación del punk rock de São Paulo y la región ABC Paulista en las imágenes de portadas de discos long playing (LP). Las nociones de representación y cultura, de Stuart Hall (2016), y el texto cultural y de semiosfera, de luri Lotman (1996), serán la base para entender la portada como un elemento cultural de mediación. 26 discos componen el corpus analizado, con tres colecciones seminales del movimiento y 23 lanzados por siete bandas importantes de São Paulo en los años 80 y principios de los 90: Cólera, Garotos Podres, Inocentes, Mercenárias, Olho Seco, Ratos de Porão y Restos de Nada. Las representaciones ocurren en imágenes figurativas y abstractas de cuatro maneras básicas: collage y estética "sucia"; figuración del personaje punk; imágenes de violencia, abyección y tensión: criticas al capitalismo y a la sociedad de consumo.

Palavras clave: Punk rock. Portada de disco. Representación.

\section{(c) (i)}




\section{Introdução}

Como já indicou Keith Negus em clássico trabalho sobre as relações entre os gêneros e a produção musical, "diferentes gêneros musicais se associaram a distintas imagens e as significam. Essas, por sua vez, conotam atitudes, valores e crenças particulares. Ao mesmo tempo, as imagens visuais denotam sons especificos" (NEGUS, 1992, p. 66, tradução nossa). ${ }^{2}$ Mesmo tratando imagem a partir da performance dos músicos, de como os fãs reconhecem tais atitudes e as rearticulam, é possivel pensar na semiose que as imagens processam nos vínculos com as músicas. A capa do disco long playing de vinilé uma dessas séries visuais construidas para identificar artistas, gostos e estilos musicais, e o caso do punk rock é um dos mais produtivos na cultura midiática.

A música e a cultura punk nasceram na década de 1970 com bandas estadunidenses como Television, Dead Boys, Ramones e Talking Heads. Depois de uma turnê pela Inglaterra em 1976, Ramones influenciou o surgimento de grupos como Sex Pistols e The Clash (MELNICK; MEYER, 2013). Da Inglaterra, o movimento se espalhou pelo mundo.

Mais do que música, o punk se construiu em torno do corpo e de comportamentos revelados nas calças jeans rasgadas, jaquetas de couro com rebites, cortes de cabelo assimétricos e angulosos, gestualidades, gírias próprias e um campo ideológico marcado pelo anarquismo, pela violência e por críticas ao capitalismo, à mercantilização da música e às instituições que estavam na base da sociedade, como família, igreja e estado. A rigor, eram também duas formas de conceber o punk: de um lado, mais ideológico e engajado, como nos EUA, e de outro, mais individualista, ligado à moda e, consequentemente, ao design, como na Inglaterra (DE VILLE, 2003).

O ideário punk apontava para soluções alternativas dentro do lema "faça você mesmo" (do it yourself - D/Y e de práticas coletivas. Nas músicas, os timbres distorcidos da guitarra, os graves acentuados do baixo, as batidas duras e pesadas da bateria, poucos acordes na harmonia e o canto gritado traduziam no som a violência das palavras de ordem contra o sistema. Como construção estética múltipla, o punk se materializou nos objetos e nos corpos dos jovens, nas imagens e nos sons, no gestual agressivo nos palcos. Como meios de comunicação e divulgação, o movimento lançou mão de shows, fanzines - folhetos alternativos produzidos a baixo custo - e discos, cujas capas traduziam visualmente suas propostas e a ruidosa música gravada.

Quanto à indústria fonográfica, a posição desses jovens era de crítica. Estavam distantes do alto padrão de produção das grandes bandas do rock progressivo, como Pink Floyd, por exemplo, cujas capas eram produzidas pela agência britânica de design Hipgnosis, de Storm Thorgerson e Aubrey Powell (ALLEYNE, 2014). Enquanto os álbuns desses grupos traziam projetos gráficos de alto profissionalismo, a proposta punk era a de criar pequenos selos ${ }^{3}$ para produzir seus discos de forma alternativa e se distanciar do que diziam ser um uso mercadológico da música e dos artistas pelas gravadoras: 4

Punks denunciaram as corporações fonográ-
ficas multinacionais, e dezenas de pequenos
selos apareceram para gravar e lançar a nova
música. Para essas pequenas gravadoras, a
música e os músicos eram seus motivos de
existência, não a realização da motivação do
lucro. O punk tentou formular suas próprias
regras, que frequentemente apareciam nas
páginas dos fanzines reunidos apressadamente
(JONES; SORGER, 1999, p. 79, tradução nossa). 5

Mesmo com tais criticas, as bandas participaram do mercado fonográfico em graus distintos: algumas em gravadoras de razoável destaque e a maioria nas bordas do sistema em selos independentes. O punk utilizou o disco como mídia para

\footnotetext{
2 Do original: Different genres of music have become associated with and signify different images, which in turn connote particular attitudes, values and beliefs. At the same time, the visual images denote particular sounds.

3 Na Inglaterra, por exemplo, selos como Stiff, Rough Trade, Illegal, Raw e New Hormones (DE VILLE, 2003, p. 158).

4 Segundo Aubrey Powell, da Hipgnosis, em tom crítico ao punk, "não foi o CD que matou as capas de disco, foi a música punk" (POWELL apud ALLEYNE, 2014, p. 259). Do original: it wasn't [the] CD format that killed the album covers, it was punk music.

5 Do original: Punks denounced multinational record corporations, and dozens of small labels appeared to record and release the new music. For these labels, the music and the musicians were the reasons for the label's existence, not the fulfillment of a profit motive. Punk attempted to formulate its own rules, which often appeared in the pages of hastily assembled fanzines.
} 
apresentar sua estética na música e em corpos e imagens que compunham as capas. Longe das composições surrealistas e imaginárias da Hipgnosis, as capas do punk eram produzidas de maneira mais anárquica. Parte da influência veio do potencial destruidor do dadaismo capaz de "sujar" a imagem para traduzir a rebeldia do movimento: "[...] cores diurnas, lettering rasgado e de má qualidade, elementos reciclados e imagens chocantes, as capas foram projetadas (ou 'não projetadas') com o uso de materiais baratos" (JONES; SORGER, 1999, p. 80, tradução nossa). ${ }^{6}$

$O$ adjetivo "má qualidade" precisa ser relativizado. A nova proposta de design, como na música e na moda, se construiu por meio do mal gosto e da violência. Se o niilismo de sua estética parecia redutor, a "[...] atitude prática do 'faça você mesmo' era imensamente libertadora" (DE VILLE, 2003, p. 157, tradução nossa), ${ }^{7}$ base para sua criatividade.

No Brasil, as capas dos discos do punk nacional seguiram, em grande parte, essa tendência. As adaptações foram fruto de três situações: menor disponibilidade de recursos na produção gráfica, questões locais do cotidiano na periferia e da violência policial e, por fim, engajamento crítico por estarem inseridos no periodo final da ditadura civil-militar e na abertura política.

O objetivo deste artigo é analisar as representações do punk rock de São Paulo e do ABC paulista, ${ }^{8}$ estruturadas nas capas de discos LP de vinil9. Além do entendimento da capa como objeto semiótico e midiático, utilizaremos como base as noções de representação, a partir de Stuart Hall (2016), de texto cultural e semiosfera da semiótica da cultura de luri Lotman (1996) e elementos da Gestalt para análise visual (DONDIS, 2003). O corpus é composto por 26 LPs, sendo as três primeiras coletâneas coletivas que abriram o punk nacional - Grito suburbano (1982), O começo do fim do mundo (1983) e SUB (1983) - e 23 trabalhos originais (exceto discos ao vivo) lançados por sete grupos paulistas importantes na década de 1980 e início de 1990: Cólera (4 LPs), Garotos Podres (4), Inocentes (5), Mercenárias (2), Olho Seco (1), Ratos de Porão (6) e Restos de Nada (1).

A contribuição do artigo está em duas frentes: análise de um objeto midiático - a capa de disco - pouco tratado em pesquisas em comunicação sobre música popular; e, com a discussão sobre a produção visual das capas, adensamento das pesquisas já existentes sobre o movimento punk paulista.

\section{Capa e representação}

Segundo Stuart Hall (2016, p. 32), resumidamente, "representação diz respeito à produção de sentido pela linguagem". É uma forma de descrever, retratar ou simbolizar um fenômeno, físico ou imaterial, colocando os signos no lugar do referido fenômeno para indicá-lo e nomeá-lo. A rigor, representar é criar uma relação inteligivel e compartilhada socialmente entre determinada coisa e alguma ideia ou conceito traduzidos em linguagem. Essa relação, apesar de construída e com certo grau de indeterminação, é o que se define como significação.

Sem serem precisos, mas com razoável rigor para indicar fenômenos ao nosso redor, os processos de significação são construidos no campo de cultura e da sociedade e se fundamentam em dois sistemas de representação: as representações mentais e os sistemas de linguagem (HALL, 2016). As representações mentais conectam conceitos às coisas ou ideias que percebemos. São relações construidas e compreendidas conforme determinados parâmetros de reconhecimento dentro da cultura (como similaridade e diferença), e que dependem de certas maneiras de organizar e classificar os fenômenos, modos esses partilhados pela sociedade. Esses modos são sistemas, ou "mapas mentais", por meio dos quais interpretamos e compreendemos o mundo à nossa volta.

\footnotetext{
6 Do original: [...] day-glo colors, torn and shoddy lettering, recycled elements, and shocking images, the covers were designed (or "not designed") with the use of cheap materials.

7 Do original: [...] hands-on, DIY attitude was immensely liberating.

8 O ABC é parte da região metropolitana de São Paulo e compõe-se de sete municípios: Santo André, São Bernardo do Campo, São Caetano do Sul, Diadema, Mauá, Ribeirão Pires e Rio Grande da Serra.

9 Este artigo é parte de duas investigações dos autores: uma sobre a produção musical do grupo Ratos de Porão e outra sobre as capas de disco do rock brasileiro.
} 
Tais sistemas, no entanto, só se concretizam se forem expressos em linguagem para produzir determinados sentidos a respeito das coisas para nós: "qualquer som, palavra, imagem ou objeto que funcionem como signos, que sejam capazes de carregar e expressar sentido e que estejam organizados com outros em um sistema" (HALL, 2016, p. 37). As linguagens são, portanto, o segundo sistema que materializa os sistemas organizativos em representação e sentido para serem articulados como processos de entendimento do mundo da cultura.

Por serem construções sociais e históricas, as representações são mutáveis. Os processos de semiotização e os compartilhamentos demonstram suas instabilidades, pois representam indiretamente tanto os padrões mais hegemônicos como demandas de determinados grupos sociais, gostos ou preferências simbólicas particulares, muitas vezes contrárias aos modelos dominantes na sociedade. De alguma maneira, no caso das imagens, servem para construir simbolicamente a identidade cultural e estética de determinado grupo social. São padrões de formas, cores e traços que compõem o repertório que permite o reconhecimento identitário. Como veremos no caso das capas de disco do punk paulista, criaram-se e compartilharam novos padrões de representação visual da música, da juventude e da cultura do rock bastante distintos dos considerados hegemônicos e cujos espaços de produção, circulação e consumo serão negociados por bandas jovens visando a construção da identidade punk. As relações entre música e imagem materializada no design se tornam importantes ferramentas para observar a história a partir da perspectiva de um grupo social. O design ganha sentidos de "tradutor e mantenedor da sociedade na qual ele se inscreve" (RODRIGUES, 2006, p. 77).

Além de objetos ou espaços de negociação simbólica na sociedade, as representações são textos na cultura, signos organizados em sintaxes cujas funções são comunicar, produzir sentidos e materializar memórias (LOTMAN, 1996). Como todo texto cultural, representações são dinâmicas, incorporam e traduzem outros textos que circulam na cultura (ou semiosfera, espaço abstrato de circulação e articulação de textos e linguagens) e informações guardadas na memória da cultura que sempre reaparecem em novas configurações. Por conta dessa função mnemônica, todo texto torna-se uma espécie de microcosmo da semiosfera que o define: ".... todo pedaço de uma estrutura semiótica ou todo texto isolado conserva os mecanismos de construção de todo o sistema" (LOTMAN, 1996, p. 31, tradução nossa). ${ }^{10}$ Pensar a capa de disco como texto da cultura é tratá-la eminentemente como representação, pois é produto de um processo de modelização da cultura que traduz no próprio texto o sistema construido no todo.

É, portanto, nos cruzamentos desses campos conceituais que pensamos as capas de disco, seja como embalagem, objeto de design, espaço de representação e texto da cultura. No mundo do consumo, a embalagem é o primeiro discurso visual e tátil referente ao objeto à venda. Além de proteger a integridade física da mercadoria, media parte do significado compartilhado entre produtor, produto e consumidor. Se uma boa embalagem deve cumprir algumas funções básicas acondicionamento, funcionalidade no manuseio, informação, identificação, imagem do produtor e venda do produto, segundo Mestriner (2002) - há outra função, mais dificil de ser mensurada, que corresponde aos valores que agrega ao produto ou que estão na mercadoria e são recompostos externamente na embalagem, ambos passiveis de serem traduzidos pelo design: o acabamento estético da embalagem (CARDOSO, 2016).

Especificamente sobre a capa de disco, Inglis (2001, p. 83-84) explica suas quatro funções: proteger o disco; fazer publicidade; acompanhar a gravação com fotos, letras transcritas etc.; ser ela própria uma mercadoria, como outras formas de arte comercial. Como se vê, a capa nos parece um objeto bastante peculiar e complexo sobretudo por seus valores simbólicos traduzidos em sua materialidade, seus sentidos visuais, o valor de 
memória e afeto, sua integridade como mídia.

A forma das capas dos LPs mudou pouco: um quadrado de $31 \mathrm{~cm}$ de lado feito de papel cartão duplex com gramatura entre $180 \mathrm{gm}^{2}$ e $450 \mathrm{gm}^{2}$, dobrado e colado nas laterais com abertura em um dos lados para inserir o disco, podendo ter encarte ou divisões que permitem abertura lateral como um álbum (SASTRE; MARTEL, 2016). No entanto, são essas condições de tamanho, manuseio e visibilidade que a tornam um dispositivo importante que contém a imagem e condicionam sua produção e leitura. Conforme Aumont (1993, p. 135), dispositivo é o conjunto de "meios e técnicas de produção das imagens, seu modo de circulação e eventualmente de reprodução, os lugares onde elas estão acessiveis e os suportes que servem para difundi-las". A capa é o artefato que contém a imagem e seu potencial semiótico de representação. Seu formato, sua produção, as possibilidades de manipulação e as situações de visibilidade (disposição na discoteca, distância das mãos ao olhar, moldura que recorta a imagem, aspectos de tateabilidade, presença de encarte, textos e imagens) demarcam a experiência de quem a vê na relação estabelecida entre imagem e música. Assim, como artefato manuseável e inteligivel, ela articula também os sentidos da audição (a música), a visão (imagem) e o tato (REZENDE, 2006). Nessas condições do dispositivo, sua singularidade e seu potencial de criação estão na produção da imagem impressa, resultado de um projeto de design que busca relacionar os principais referenciais do disco que embala: artista, música gravada, gênero, movimento cultural a que se vincula e gravadora.

Relacional e denso como todo texto cultural e sempre produto de negociações entre interesses distintos (estéticos, econômicos, de consumo), à capa vinculam-se muitas camadas de sentido. Não é simples embalagem, objeto efêmero e descartável. Mais do que proteger o disco e ter funcionalidade, ganha autonomia e sofisticação enquanto objeto estético e se torna singular espaço de representação ao construir traduções visuais da obra musical que contém.

Tais valores simbólicos são importantes em vários aspectos sob os quais ela é pensada: no consumo, é campo especial de contato entre artista e público; na cultura das midias, é produto midiático particular em que se dá negociação de gostos e construção de representações na mediação música-artista-público; na estética das midias, é obra que aciona sensibilidades e tendências de gosto que acompanham a experiência estética da audição, da visão e do tato; por fim, observada desde o presente, é possível pensar a capa como objeto de memória, pela articulação de afetos e sentidos que mobiliza (VARGAS; BRUCK, 2020).

\section{Punk em S. Paulo e no ABC}

No final da década de 1970, dois mediadores foram responsáveis pela difusão do punk no Brasil: Kid Vinil, DJ da então rádio Excelsior FM, e o disco A Revista Pop apresenta o Melhor do Punk Rock (1977) (GOZZI; BELINTANI, 2015). Esse disco estava vinculado à então revista Pop, publicação sobre rock e música da época, responsável por introduzir diversos grupos estrangeiros (BORGES, 2005), como recorda João Gordo, vocalista do Ratos de Porão:

Com Sex Pistols, Ramones, The Jam, Ultravox, London, Stinky Toys e outros. Foi a primeira vez que ouvi Ramones. Fiquei alucinado com aquilo. Não tinha solo, a guitarra parecia uma serra elétrica, era muito moderno o bagulho [...] o Sex Pistols eu vi pela primeira vez na Veja, numa matéria do Okky de Souza. [...] Tinha uma foto de um monte de punks andando em Londres, todo mundo com aquele visual do Sid Vicious. ${ }^{11}$ Eu arranquei as páginas da matéria e levei para casa (GORDO apud BARCINSKI, 2016, p. 45).

O punk era composto por formas rebeldes e alternativas de expressão estética da juventude da periferia reprimida pela ditadura:

O objetivo desses punks era expressar sua fúria
de uma maneira áspera e original. A coisa mais
odiada no mundo era alguém que fosse um
conformista assumido. Muitas bandas punk
montaram suas plataformas ou mensagens
baseadas no não-conformismo. O conformismo
é rejeitado em todas as frentes possiveis a fim
de perseguir a verdade ou às vezes apenas
para chocar as pessoas (O'HARA, 2005, p. 32). 
O inconformismo contra à repressão foi importante na época em que a ditadura ensaiava uma tênue abertura. A repressão continuava nas ruas, nas ações da Polícia Militar que não permitia grandes aglomerações. Foram comuns os eventos punks não finalizados por proibição policial, prisões, brigas com outras tribos urbanas, expulsões etc. A luta dessa juventude pouco afeita ao intelectualismo passava pelas opções violentas e corporais de resposta, tanto na briga propriamente dita quanto na mera aparência. Na visão desses garotos da periferia, os artistas da MPB haviam se "acomodado" à ideia de um amanhã democrático e com certo sucesso comercial, e a música da Vanguarda Paulistana e sua ação independente eram elitizadas e cultas demais.

De início para demarcar território, as disputas entre gangues passaram a ser entre os punks do ABC e os de São Paulo:12 os da capital eram considerados ricos, com jaquetas de couro de verdade e coturnos engraxados, trabalhando em escritórios como office boys; enquanto os do ABC vestiam macacões de operários e botas de fábrica.

No início da década de 1980, surgiram mais bandas, salões e casas de shows, além dos fanzines que passaram a circular pelas grandes galerias (centros comerciais) do centro de São Paulo. Muitos grupos começaram a gravar compactos ou extented play (EPs) em selos pequenos que surgiam na onda da cultura independente, tais como Punk Rock Discos, Ataque Frontal, Devil Discos, Baratos Afins, Cogumelo Records, entre outros. Os discos compactos funcionavam como entrada de um artista no mercado. As gravadoras lançavam o pequeno disco para testar o trabalho musical perante o mercado. Caso houvesse boa vendagem, investia-se na gravação do LP (VICENTE, 2014). No caso dos punks, em selos alternativos, o compacto tinha produção mais barata e funcionava como peça de registro e divulgação. Com o passar do tempo, alguns grupos assinaram contrato com grandes gravadoras, caso de Inocentes (WEA) e Mercenárias (EMI), mas foram exceções e a aproximação durou pouco.

Em 1982, três bandas - Inocentes, Cólera e Olho Seco - gravaram o primeiro registro do movimento. Grito suburbano contou com doze músicas, duas de cada grupo de cada lado do LP, com um total de 19min32 de duração. A gravação foi precária:

\begin{abstract}
No estúdio da Gravodisc, uma gravadora especializada em música evangélica, na rua dos Timbiras, 81, atrás da loja Punk Rock [...] O som ficou péssimo. Decidiram refazer. Eram tão inexperientes que não sabiam que bastava remixar. Refizeram tudo de novo, todas as bandas, em oito horas (NASCIMENTO; PAIVA, 2016, p. 75).
\end{abstract}

A coletânea foi precursora de algo que caracterizaria o movimento: a ideia de ação coletiva como característica da produção de discos e shows. No mesmo ano, organizaram o festival $O$ começo do fim do mundo, com a proposta de selar a paz entre os punks do ABC e de São Paulo. ${ }^{13}$ Foram dois dias de shows (dez bandas por dia) e exposições no SESC Pompéia, zona oeste da cidade de São Paulo. O festival foi gravado em fita cassete e depois passado para vinil tornando-se outro documento sonoro importante.

No ano seguinte foi lançado o álbum SUB, com quatro bandas - Cólera, Fogo Cruzado, Psykóze e Ratos de Porão - e seis músicas de cada. A capa do disco original de época tinha sua abertura para o lado contrário, a cor vermelha atingida não era a desejada e os nomes das músicas do Ratos de Porão e do Psykóze estavam trocadas no selo do vinil. Esse disco foi o último com essa característica coletiva.

\section{As capas do punk}

Desses primeiros grupos de punk rock surgidos no início dos anos 1980, em S. Paulo e no $A B C$, os que mais se destacaram foram: Cólera, Garotos Podres, Inocentes, Mercenárias, Olho

\footnotetext{
12 Para um histórico do movimento punk em audiovisual, sugerimos dois documentários: Botinada: a origem do Punk no Brasil, dirigido por Gastão Moreira (2006), e Guidable: a verdadeira história do Ratos de Porão, dirigido por Fernando Rick e Marcelo Appezzato (2008). As referências completas estão ao final do artigo.

13 Infelizmente, o evento no SESC não selou a paz. Ao final do segundo dia, houve uma briga generalizada entre as facções que, depois, se juntaram e se voltaram contra a Polícia Militar.
} 
Seco, Ratos de Porão ${ }^{14}$ e Restos de Nada. Nos 23 LPs que totalizam suas discografias, mais as três coletâneas (ver Quadro 1), não há uma tendência geral de tipo de capa, mas formas variadas de a estética punk ser traduzida visualmente.

Quadro 1 - Relação de discos LP e artistas em análise

\begin{tabular}{|c|c|c|c|}
\hline Artista & Disco & Selo & Ano \\
\hline Coletânea & Grito suburbano & Punk Rock Discos & 1982 \\
\hline Coletânea & O começo do fim do mundo & Punk Rock Discos & 1983 \\
\hline Coletânea & SUB & Estúdios Vermelhos & 1983 \\
\hline \multirow{4}{*}{ Cólera } & Tente mudar o amanhã & Ataque Frontal & 1984 \\
\hline & Pela paz em todo mundo & Ataque Frontal & 1986 \\
\hline & Verde, não devaste! & Devil Discos & 1989 \\
\hline & Mundo mecânico, mundo eletrônico & Devil Discos & 1992 \\
\hline \multirow{4}{*}{ Garotos Podres } & Mais podres do que nunca & Rockers Produções & 1985 \\
\hline & Pisando na m... & Lup Som & 1987 \\
\hline & Pior que antes & Continental & 1988 \\
\hline & Canções pra ninar & Radical Records & 1993 \\
\hline \multirow{5}{*}{ Inocentes } & Adeus carne & WEA & 1987 \\
\hline & Miséria e fome & Devil Discos & 1988 \\
\hline & Inocentes & WEA & 1989 \\
\hline & Estilhaços & Camerati & 1992 \\
\hline & Subterrâneos & Estúdio Eldorado & 1994 \\
\hline \multirow{2}{*}{ Mercenárias } & Cadê as armas? & Baratos Afins & 1986 \\
\hline & Trashland & EMI & 1988 \\
\hline Olho Seco & Olho por olho & Cogumelo Records & 1989 \\
\hline \multirow{6}{*}{ Ratos de Porão } & Crucificados pelo sistema & Punk Rock Discos & 1984 \\
\hline & Descanse em paz & Baratos Afins & 1986 \\
\hline & Cada dia mais sujo e agressivo & Cogumelo Records & 1987 \\
\hline & Brasil & Roadracer Records & 1989 \\
\hline & Anarkophobia & Estúdio Eldorado & 1990 \\
\hline & Just another crime... in Massacreland & Roadrunner Records & 1994 \\
\hline Restos de Nada & Restos de nada & Devil Discos & 1987 \\
\hline
\end{tabular}

Fonte: elaborado pelos autores (2019).

$\mathrm{Na}$ análise do corpus, foi possivel detectar quatro grandes estratégias de representação na imagem figurativa e na composição abstrata e elementos visuais do design - cor, equilibrio, contraste, forma etc. (DONDIS, 2003): a) colagem e a estética da "sujeira", com mau acabamento;

b) figuração do corpo do personagem punk;

14 O primeiro disco do Ratos de Porão - Crucificados pelo sistema - é considerado punk. Nos seguintes, o grupo passou a ser vinculado a outros subgêneros até se autodenominar crossover. No entanto, foi mantido no corpus da pesquisa pelo trabalho gráfico de suas capas, os vínculos visuais que manteve com o movimento e sua importância no início do punk em São Paulo. 
c) violência, rebeldia, figuras abjetas, tensão e agressão traduzidas em imagens figurativas ou abstratas;

d) crítica ideológica ao capitalismo e à sociedade.

As capas serão analisadas nessas quatro categorias, descritas e analisadas como textos culturais a partir da noção de representação e das características estéticas do punk. Várias capas trazem mais de um desses aspectos compositivos, o que dificulta a abordagem uma a uma. Assim, para cada categoria, serão citados e comentados um ou dois exemplos.

\section{Estética "suja" e colagem}

Seguindo a estética dos fanzines e a proposta do "faça você mesmo", várias capas foram feitas de maneira propositalmente amadora seguindo as características do movimento: rebeldia e crítica aos padrões sociais e contra design bem-acabado. Dai o uso da colagem aparentemente desorganizada. Como havia pouco investimento, as capas deveriam ser baratas. Uma solução recorrente era algum músico ou amigo fazer a arte, as fotografias ou os desenhos, o que, em muitos casos, comprometia a qualidade técnica do produto final. No entanto, se a falta de recursos e a postura crítica, às vezes, redundavam em trabalhos ruins, em outras situações, era condição fundamental para os selos que produziam as capas buscarem soluções criativas (JONES; SORGER, 1999). Ou seja, os questionamentos acionados pela estética punk também atingiam os padrões mais conhecidos de design das capas e promoviam novas experiências no dispositivo (DE VILLE, 2003).

A primeira coletânea, Grito suburbano, já trazia esse aspecto, como se vê em sua capa e contracapa (Figura 1 e 2), na arte feita pelos músicos Rédson, Fábio Sampaio e seus irmãos Gazola e Mazola. Na parte superior à esquerda da capa, há os logotipos e nomes das bandas (Inocentes, Cólera e Olho Seco) e o título do álbum em vermelho na diagonal. Em toda ela se vê fotos sobrepostas e mal cortadas sobre fundo branco que só aparece na parte superior para contrastar com o nome do disco. As imagens são de shows, amigos e punks nas ruas de São Paulo. $\mathrm{Na}$ contracapa estão fotos dos grupos, nomes e os integrantes. Abaixo, os agradecimentos às pessoas do movimento, amigos e divulgadores (Kid Vinil e fanzines).

Figura 1 - Grito suburbano - capa (1982)

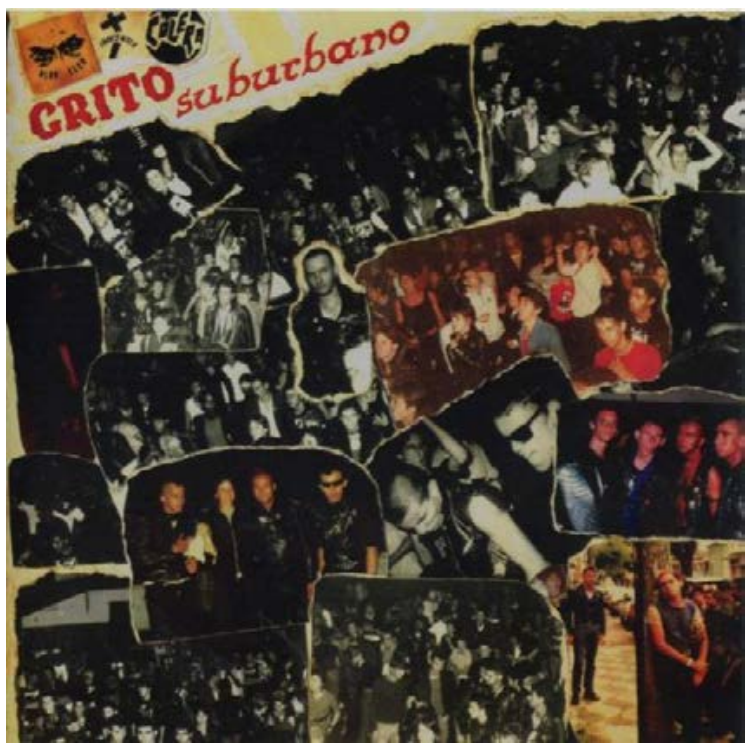

Fonte: Site Discogs. ${ }^{15}$

Figura 2 - Grito suburbano - contracapa (1982)

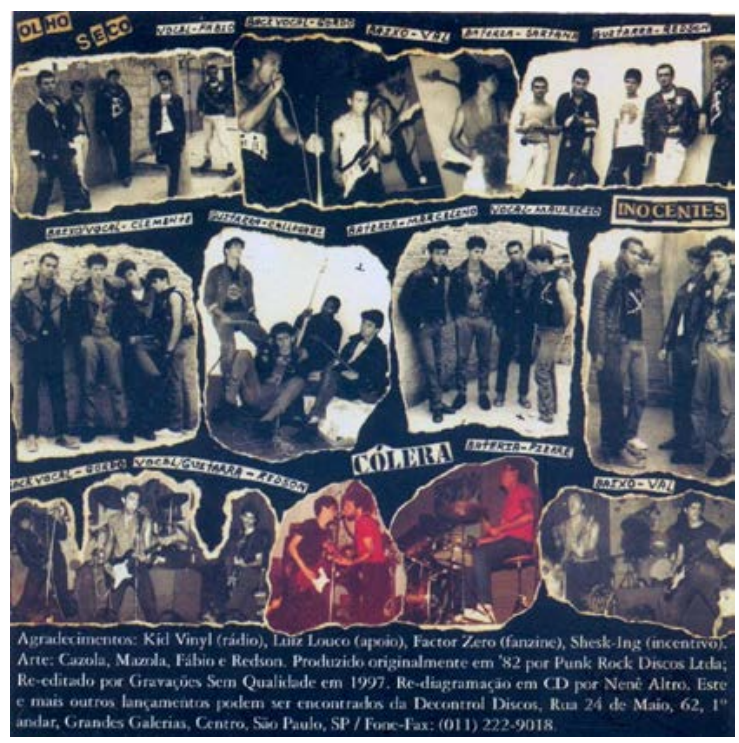

Fonte: Site Discogs. ${ }^{16}$ 
A capa da segunda coletânea, O começo do fim do mundo, também seguia a proposta. O disco foi gravado ao vivo, com uma música de cada banda que tocou no festival no SESC Pompéia. ${ }^{17}$ Organizado pelo dramaturgo Antonio Bivar e por Callegari (guitarrista do Inocentes), o som foi capturado em fita cassete estéreo e reprocessado em estúdio em dois canais. Por isso, alertam nos agradecimentos: "A qualidade da gravação não é muito boa".

A capa, sem o nome do disco (que veio na contracapa), foi feita por uma colagem (Figura 3) com imagens daqueles que, para os punks, iniciariam na época o apocalipse anunciado: presidente dos EUA Ronald Reagan em destaque ao centro, primeira ministra britânica Margaret Thatcher à esquerda, o presidente brasileiro João Figueiredo, o líder soviético Leonid Brejnev, o Aiatolá Khomeini, Papa João Paulo II, o ditador argentino Leopoldo Galtieri, Menachem Begin, primeiro ministro de Israel, além de tropas militares, cadáveres e caveiras. As imagens desses personagens e a forma desorganizada de sua distribuição no plano pela colagem indicam as críticas que o movimento faz aos ditadores, às instituições conservadoras (igreja, polícia, estado) e aos líderes neoliberais da época.

Figura 3 - o começo do fim do mundo - capa (1983)

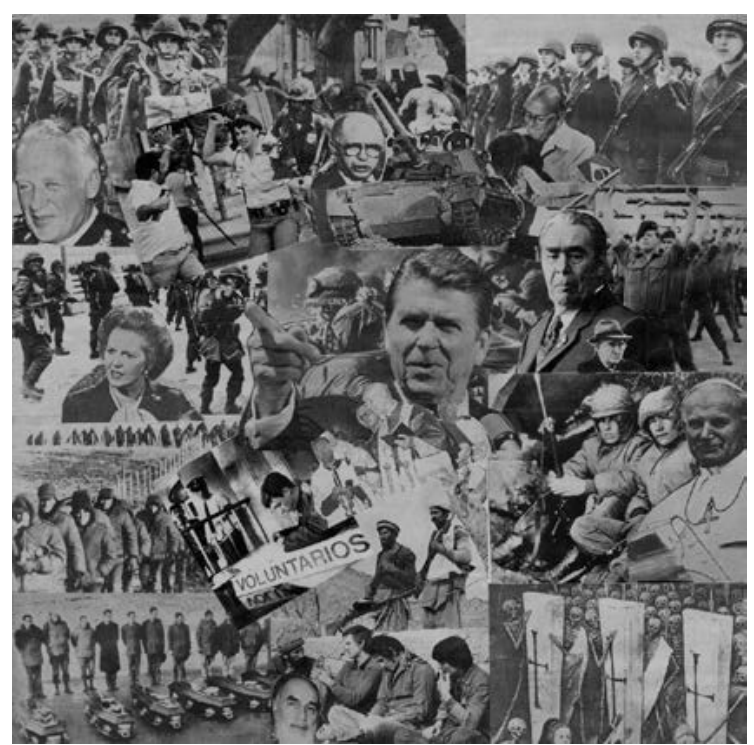

Fonte: Blog do Barcinski - UOL. ${ }^{18}$
A técnica da colagem, além de demonstrar a "imperfeição" visual do punk, resulta em um trabalho de design direto na comunicação do movimento. Na imagem feita por essa técnica, perdem-se as noções de tempo e espaço de representação, pois cada fragmento demarca uma realidade distinta. Mesmo que se construa uma narrativa fracionada, múltipla e descentrada, passivel de ser "lida" em várias direções, a colagem revela seus sentidos nas relações estabelecidas entre cada excerto e o conjunto. Por sua própria natureza, é um tipo de texto cultural produzido em contatos com vários outros textos e se adensa na dinâmica de tais relações.

A contracapa (Figura 4) traz uma foto da plateia para retratar a atmosfera do festival: diversos punks com punhos cerrados - gesto característico de violência, resistência e de partilha de gosto pelo som -, roupas surradas, braceletes de espinhos, rebites, jaquetas de couro, camisetas rasgadas e cortadas, cabelos curtos arrepiados ou no formato de moicano. A perspectiva atrai o olhar e acentua a profundidade da cena. Os braços erguidos e os corpos amontoados indicam o dinamismo do momento. Diferente da capa, em que a colagem elimina a noção de espaço e de contexto, ambos indicializados pelas imagens em fragmentos, a foto da contracapa situa o local onde ocorre a ação: as paredes de tijolo aparente da antiga fábrica transformada em centro cultural pelo projeto da arquiteta Lina Bo Bardi. Como objetos de memória, tijolos e fábrica marcam a origem operária e marginal dos punks, em especial os do ABC paulista. É possivel perceber que a representação visual "suja" estabelece um contraponto à estética dominante dos álbuns em que o artista aparece atraente no centro da capa. O punk negocia esse espaço em novos padrões estéticos.

\footnotetext{
17 Ulster foi a única a ficar de fora. Os músicos acreditavam que tiveram seu som prejudicado propositadamente no festival.

Disponivel em: https://blogdobarcinski.blogosfera.uol.com.br/2017/11/24/disco-e-shows-lembram-um-marco-do-movimento-punk-no-brasil/. Acesso em 30 nov. 2020.
} 
Figura 4 - O começo do fim do mundo - contracapa (1983)

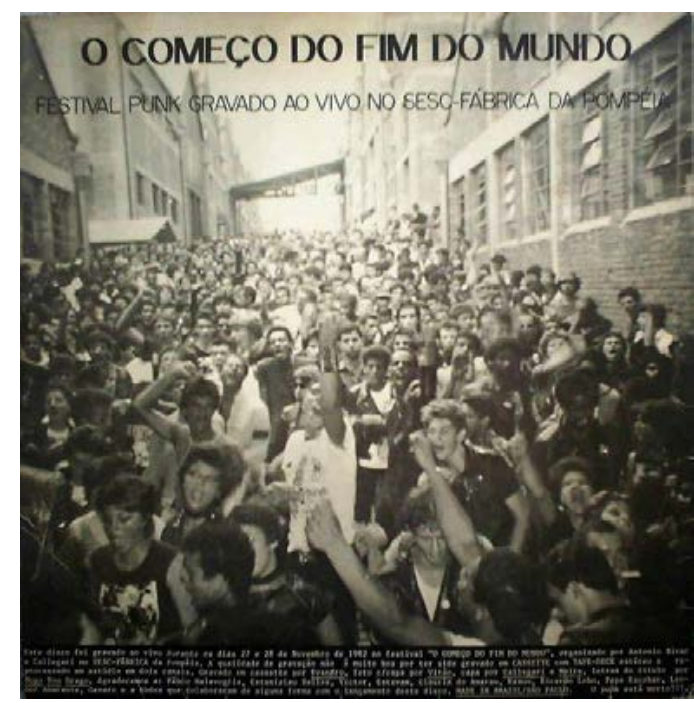

Fonte: Blog do Barcinski - UOL. ${ }^{19}$

A colagem também está no disco Tente mudar o amanhã, de 1984, do Cólera. A capa (Figura 5) chama atenção pelo contraste forte de cores preta no fundo e vermelha nas letras e fotos. A composição se baseia na leve diagonal que orienta letras e fotos com bordas rasgadas, todas com filtro vermelho. Na contracapa (Figura 6), as fotos dos músicos aparecem recortadas do mesmo jeito.

Figura 5 - Tente mudar o amanhã - capa (1984)

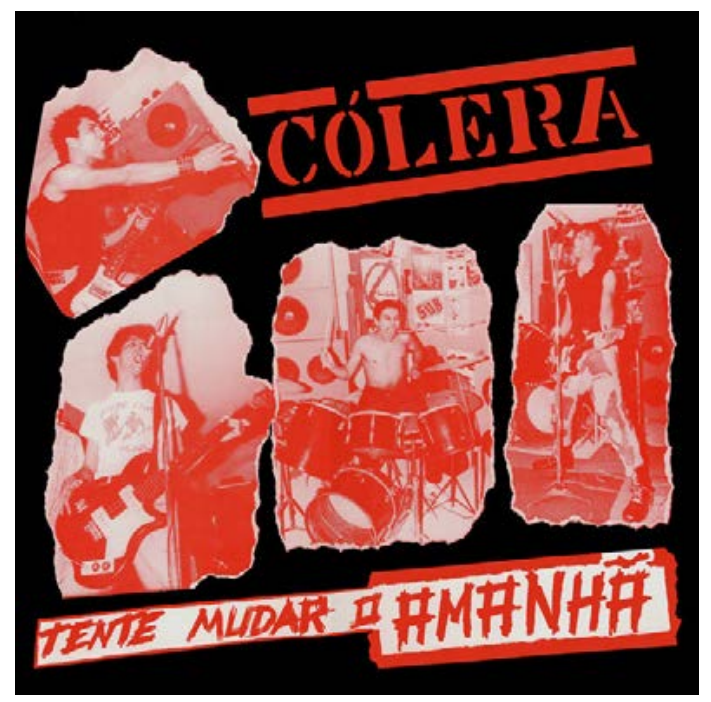

Fonte: Site Discogs. ${ }^{20}$
Figura 6 - Tente mudar o amanhã - contracapa (1984)

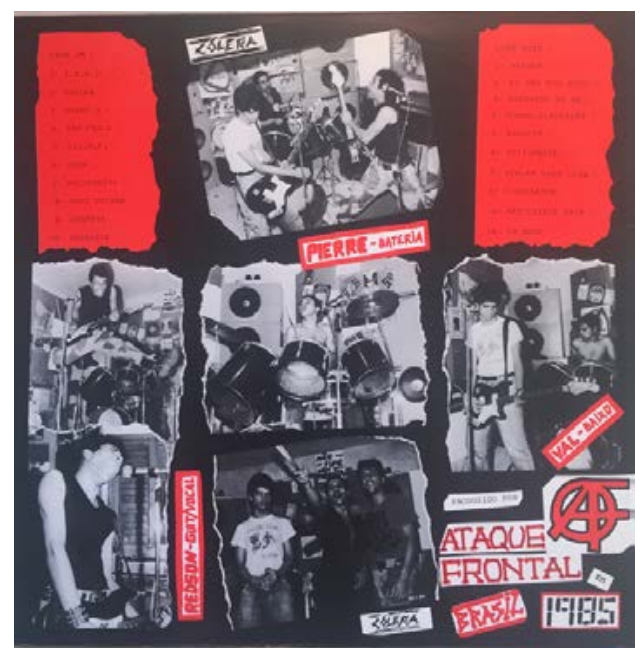

Fonte: Site Discogs. ${ }^{21}$

Além da colagem, alguns desenhos traduzem essa estética, como se vê na capa do disco Restos de nada (Figura 7), de 1987, do grupo homônimo. Desenhada por Ariel (vocalista) e Douglas Viscaino (guitarrista), há nela uma perspectiva em espaço aparentemente onírico com objetos quebrados jogados como lixo e restos de comida, em traços simples e primitivos. A imagem indica uma crítica ao consumismo exagerado e à consequente produção massiva de lixo que degrada a sociedade, como está na letra de uma das músicas: "Somos todos escravos de um balde de lixo".

Figura 7 - Restos de nada - capa (1987)

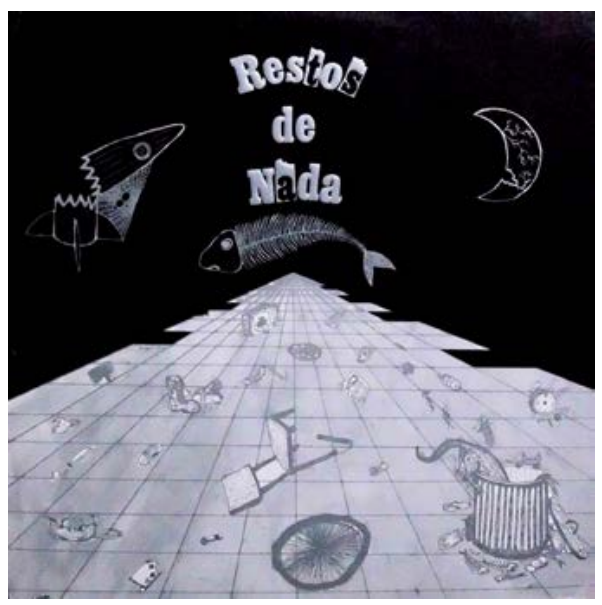

Fonte: Site Discogs. ${ }^{22}$

19 Disponível em: https://blogdobarcinski.blogosfera.uol.com.br/2017/11/24/disco-e-shows-lembram-um-marco-do-movimento-punk-no-brasil/. Acesso em: 30 nov. 2020.

20 Disponivel em: https://wwww.discogs.com/pt_BR/C\%C3\%B3lera-Tente-Mudar-O-Amanh\%C3\%A3/release/1746313. Acesso em: 02 dez. 2020. ${ }_{21}$ Disponivek em: https://www.discogs.com/pt_BR/C\%C3\%B3lera-Tente-Mudar-O-Amanh\%C3\%A3/release/1746313. Acesso em: 02 dez. 2020. 22 Disponivel em: https://www.discogs.com/pt_BR/Restos-De-Nada-Restos-De-Nada/master/1087611. Acesso em: 02 dez. 2020. 
Figura 8 - Sub - capa (1983)

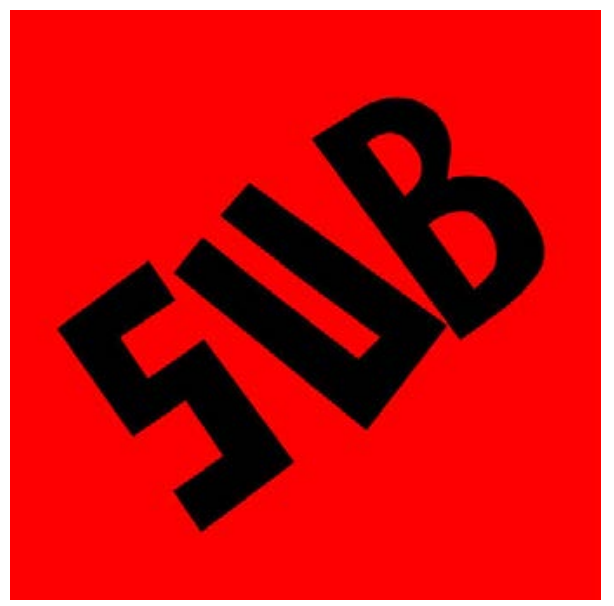

Fonte: Site Lágrima Psicodélica $5^{23}$.

Outro elemento de design que indica essa característica do punk é o lettering. Várias capas trazem os nomes dos discos e dos artistas em letras tortas e sem alinhamento - contracapa da coletânea SUB (Figura 8) - ou manuscritas - Adeus carne, dos Inocentes (Figura 9) -, ou no padrão típico da pichação, presente em várias capas do Ratos de Porão, ou ainda na colagem de letras de fontes diferentes, como no disco Restos de nada (Figura 7) e no LP Mais podres do que nunca (Figura 10), estreia do Garotos Podres. ${ }^{24}$

Figura 9 - Adeus Carne - capa (1987)

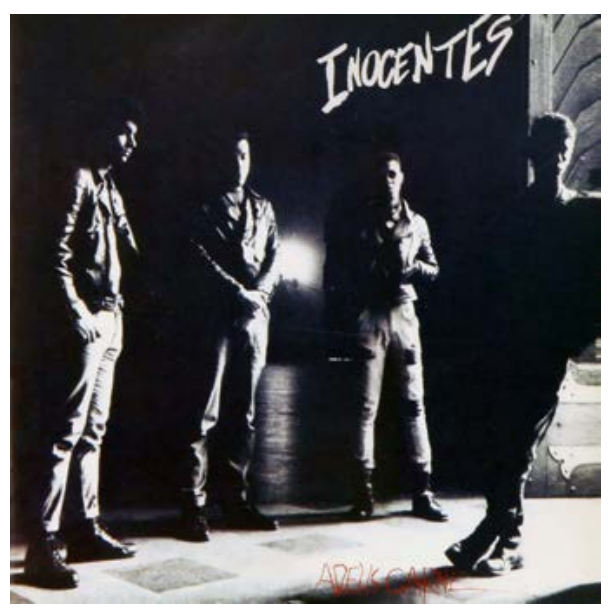

Fonte: Site Discogs. ${ }^{25}$
Figura 10 - Mais podres do que nunca - capa (1985)

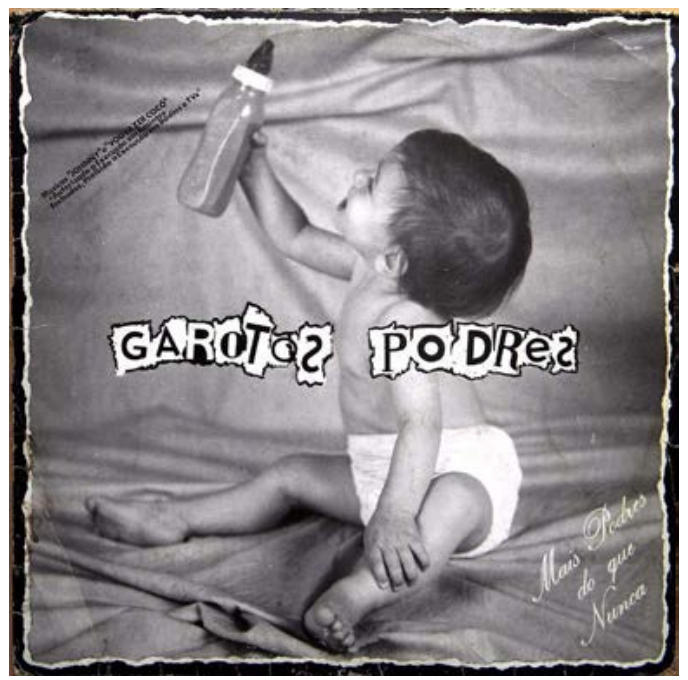

Fonte: Discogs. ${ }^{26}$

\section{O personagem punk}

Um forte aspecto de representação do punk rock nas capas foi o próprio personagem punk e a construção física e simbólica do seu corpo. Tal figura representava tanto o estilo dos músicos no palco, como dos fãs que partilhavam a construção de uma moda peculiar. O personagem tipificado estabelecia, indiretamente, pontos de identificação, de afetos e de criação de uma cultura punk, para além da música propriamente dita (NEGUS, 1992). No entanto, a nova configuração do corpo jovem deveria, por conta da imagem agressiva, negociar espaços de visibilidade e legitimidade para um mínimo de reconhecimento. Para isso, mesmo que de maneira marginal, a moda, os shows e as capas de disco funcionavam como campos de posicionamento dessas novas representações contra os padrões visuais hegemônicos.

A já citada contracapa de O começo do fim do mundo (Figura 4) demonstra esse personagem no gesto, nas roupas e nos cabelos das pessoas na plateia do festival. Nas fotos em várias capas e, principalmente, nas contracapas, essas imagens reiteram a aparência e a performance desses músicos que se propõem a ser como seu público porque vêm dele, partilham ori- 
gens, visões de mundo e desejos similares. $\mathrm{O}$ ouvinte reconhece no músico essas referências ideológicas e comportamentais e as assume na expressão corporal. A capa transforma-se em um potente elemento de mediação cultural, um dispositivo inteligente - texto cultural, conforme Lotman (1996) - capaz de articular, por meio de processos de representação, gostos e desejos reconstruidos nas imagens, sempre renegociadas frente aos padrões estabelecidos.

O personagem punk aparece em desenhos e fotografias. Como desenho está na capa de Crucificados pelo sistema (1984), do Ratos de Porão (Figura 11), onde se vê um punk figurado em traços grosseiros (cabelos de moicano, coturnos, roupa surrada) sentado sobre um capacete segurando uma bandeira com o "símbolo da paz". Vê-se aqui uma aparente contradição, pois esse simbolo era usado pelos hippies, aos quais os punks se opunham. Mesmo assim, acabou adotado pelo grupo, adaptado com a figura de um rato e de duas armas cruzadas à frente e colocado em seu logotipo, como se vê na contracapa (Figura 12). Criado em 1958 para uma campanha britânica pelo desarmamento nuclear, a figura é formada por duas letras em alfabeto semafórico: $\mathrm{N}$ e $\mathrm{D}$ (Nuclear Disarmament), dentro do circulo que representa o mundo. No caso do R.D.P., ele traduzia ideias como "poluição atômica" e "guerra desumana", presentes em suas letras.

Figura 11 - Crucificados pelo Sistema - capa azul (1984)

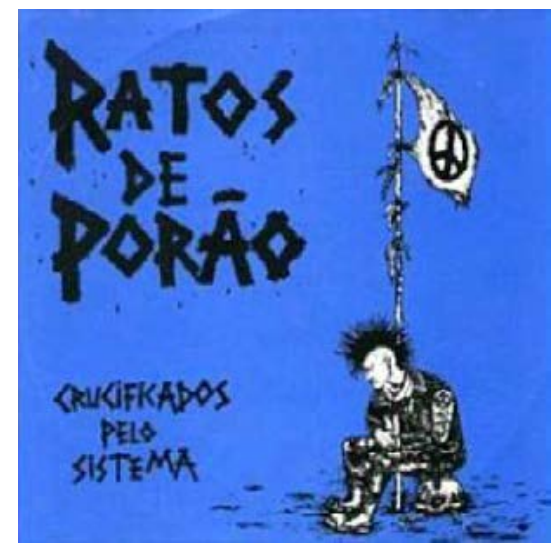

Fonte: Site Discogs. ${ }^{27}$
Figura 12 - Crucificados pelo Sistema - contracapa (1984)

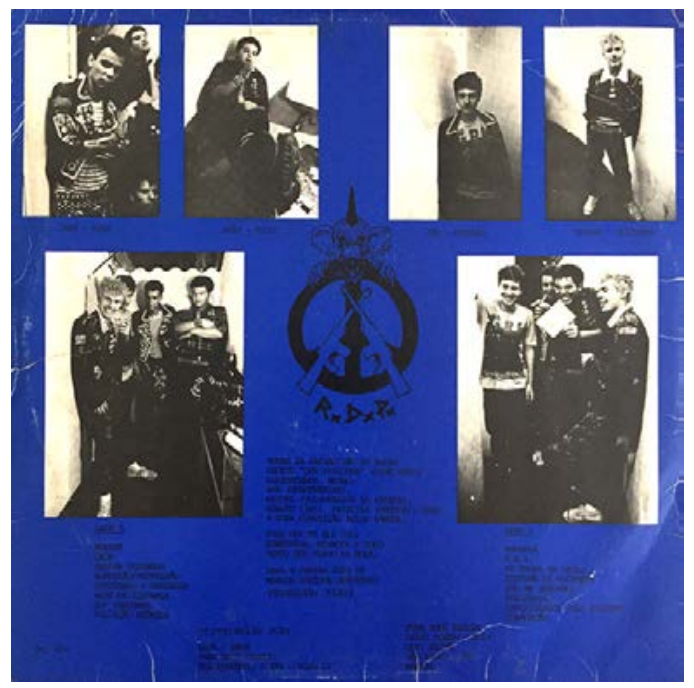

Fonte: Discogs. ${ }^{28}$

Desse LP, foram lançadas mil cópias, sendo 500 em tom azul e 500 em vermelho. As cores branco, preto e cinza apareceram em reedições posteriores.

O personagem punk também pode ser visto na imagem dos músicos das bandas, como no primeiro disco do Inocentes, Adeus carne (Figura 9). Lançado em 1987 pela WEA, uma grande gravadora, a capa difere dos outros LPs por seguir um padrão mais próximo dos grupos de sucesso com a foto dos quatro integrantes, coisa pouco usual nos discos do movimento. A imagem em preto e branco possui uma forte luz contrastada (que aumenta a tensão da cena, em sintonia com o gênero musical) e um fundo escuro em perspectiva. Nela, os músicos são retratados em figurinos reconhecidos: jaquetas de couro, calças jeans rasgadas e coturnos ou botas. Esse reconhecimento, partilhado por artistas e fãs, é parte da representação, construída por ambos e por todo o circuito mercadológico e estético que envolvia o punk: música, corpo, gesto, moda etc.

A música Pátria amada, que abre o disco, tornou-se um clássico do rock dos anos 1980. Musicaram ainda um poema do russo Maiakovski e fizeram uma versão para a música Pesadelo,

\footnotetext{
27 Disponivel em: https://www.discogs.com/pt_BR/Ratos-De-Por\%C3\%A30-Crucificados-Pelo-Sistema/release/13060233. Acesso em: 01 dez. 2020

28 Disponivel em: https://www.discogs.com/pt_BR/Ratos-De-Por\%C3\%A30-Crucificados-Pelo-Sistema/release/13060233. Acesso
} em: 01 dez. 2020 
de Paulo César Pinheiro, famosa pela gravação do MPB4. O disco vendeu bem por ser de um artista punk: 30 mil cópias. Mas, para a major que tinha o Titãs vendendo 300 mil, a margem foi baixa demais e o Inocentes ficou como grupo de segundo escalão (NASCIMENTO; PAIVA, 2016).

\section{Imagens de agressão, abjeção, tensão e desequilibrio}

Seja por meio de fotografias ou desenhos de temática abjeta, seja em composições tensivas e contrastantes no design, a maioria das capas não produzia sensações de agradabilidade ou equilibrio. Se o intuito da música e do comportamento punk era o choque, a violência e o escárnio, as imagens deveriam traduzir, em suas camadas de sentido, as posturas denunciadas nas letras, sonorizadas nos arranjos e compostas em roupas e performances. De alguma forma, dentro da semiosfera do movimento, quanto mais violentos ou escatológicos fossem os textos sonoros, poéticos e visuais, mais forte e consistente poderia ser entendido o trabalho do grupo pelo público. Músicas, shows, performances e discos tinham como parâmetro de destaque seu potencial de provocação, sua capacidade de mobilizar a atenção do fã interessado nas posições críticas e contundentes do ideário.

Uma das primeiras imagens tensivas no design da capa de um disco punk está em SUB, coletânea lançada em 1983 pelo selo Estúdios Vermelhos. A capa (Figura 8) tem uma composição aparentemente simples, porém forte na cor e no contraste: sobre um fundo vermelho tem-se o título do disco escrito em preto na diagonal. 0 contraste de cores, a temperatura elevada do vermelho e a linha diagonal provocam a sensação de instabilidade, acrescida do desalinho da letra " $U$ ", mais inclinada que as outras e com maior tensão na composição (DONDIS, 2003). O título remete ao underground, aquilo que acontecia no submundo dos punks. Já na contracapa (Figura 13), além das fotos das bandas, as letras usadas também estão desalinhadas, o que traduz as tensividades do projeto estético.

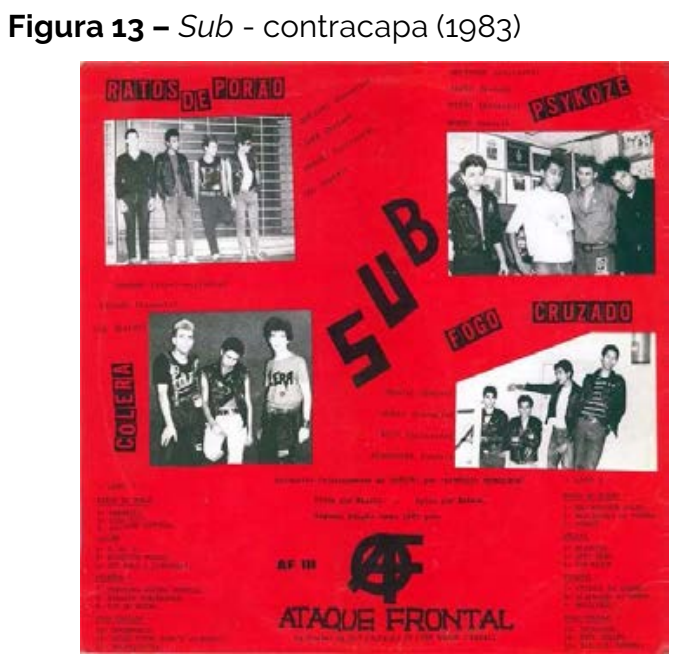

Fonte: Site Lágrima Psicodélica $5{ }^{29}$

Além do design, há capas que trabalham com imagens de objetos e cenas críticas, abjetas, escatológicas e violentas, que impactam o olhar de quem manuseia a capa e, ao mesmo tempo, atrai a atenção e o interesse dos fãs da estética punk. Dois casos são fortes. No disco Descanse em paz, de 1986, do R.D.P. (Figura 14), há em primeiro plano a foto do rosto de uma mulher negra morta em um caixão com algodões nas narinas e boca, ataduras na testa e flores brancas ao seu redor. A foto foi retirada de um jornal e mostra uma mulher que, segundo a reportagem, havia sido linchada por moradores acusada de ter cometido um roubo numa cidade da Baixada Fluminense.

Figura 14 - Descanse em paz - capa (1986)

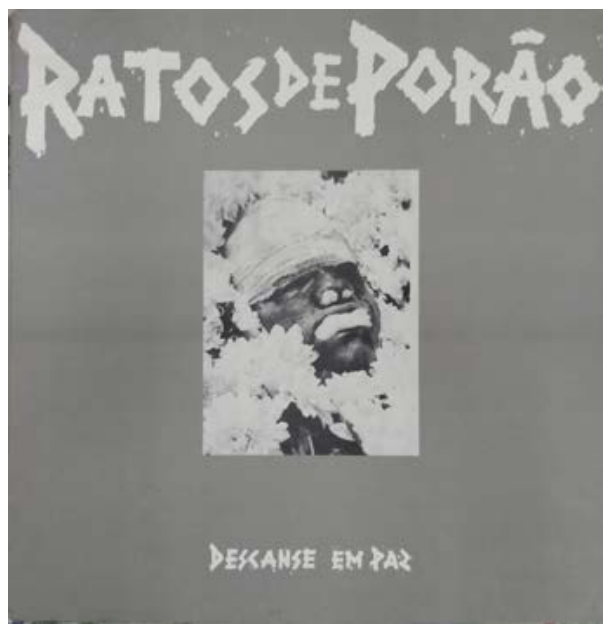

Fonte: Discogs. ${ }^{30}$ 
Outro exemplo é do LP Olho por olho, de 1989. do grupo Olho Seco (Figura 15), que mostra em perspectiva uma lata de sardinhas aberta com olhos embebidos em sangue onde deveria haver peixes em óleo comestivel. No encarte, há dois grandes desenhos estilizados, lado A e lado B (Figuras $16 \mathrm{e}$ 17), com um personagem punk mordendo um LP com um dos olhos esbugalhado, figuras de seres compostos pela junção estranha de partes do corpo, algumas escatológicas, ao lado de um cano que escoa sangue em meio às letras das músicas.

Figura 15 - Olho por olho - capa (1989)

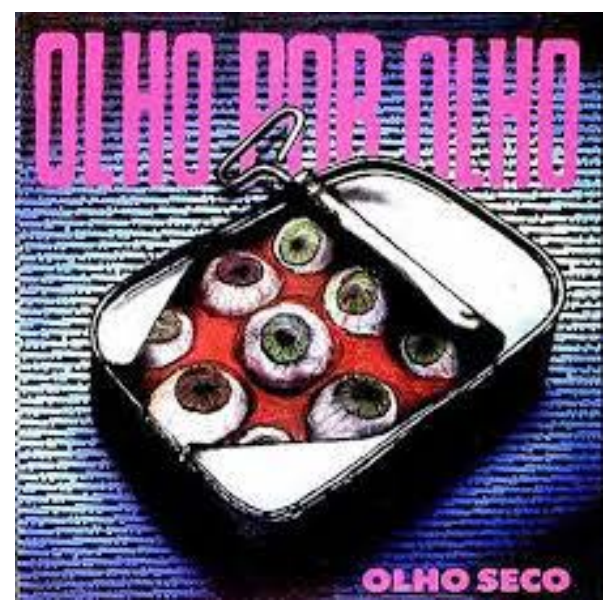

Fonte: Site Discogs. ${ }^{31}$

Figura 16 - Olho por olho - encarte lado A (1989)

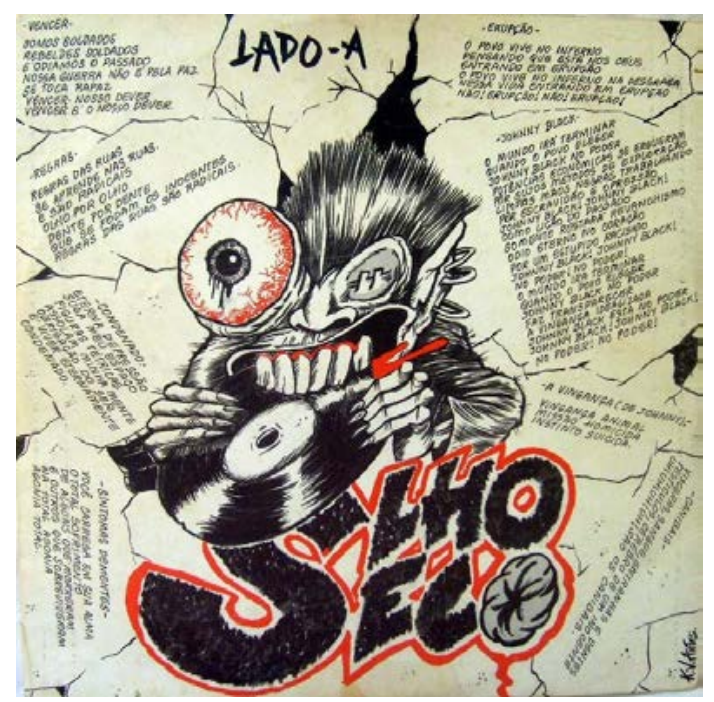

Fonte: Site Discogs. ${ }^{32}$
Figura 17 - Olho por olho - encarte lado B (1989)

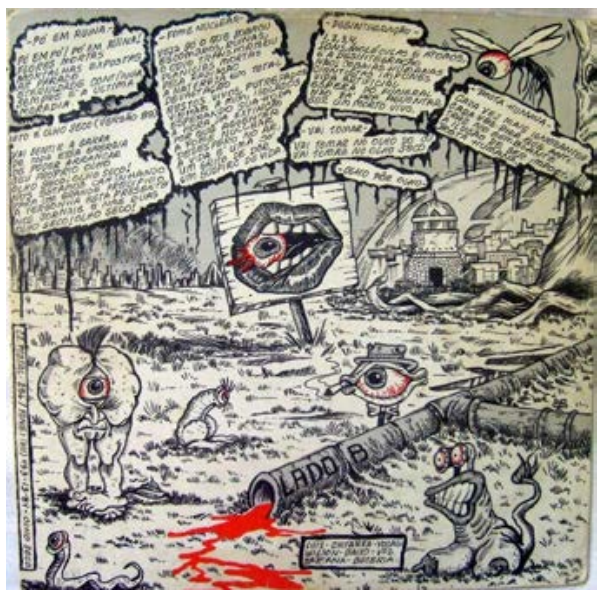

Fonte: Site Discogs. ${ }^{33}$

\section{Crítica ideológica}

A quarta estratégia de representação visual do punk tem a ver com a postura do movimento em criticar o sistema e a sociedade capitalistas em seus aspectos definidores: consumo, violência institucional, alienação, miséria, monetização, destruição do meio ambiente etc., com a capa em diálogo com as proposições indicadas nas letras das músicas. Essa postura aparece também nas três formas anteriores de representação, porém, o destaque neste item é para exemplos em que a critica é mais objetiva e clara. Nesses casos, a força das imagens é endereçada contra o sistema socioeconômico hegemônico.

Figura 18 - Cadê as armas - capa (1986)

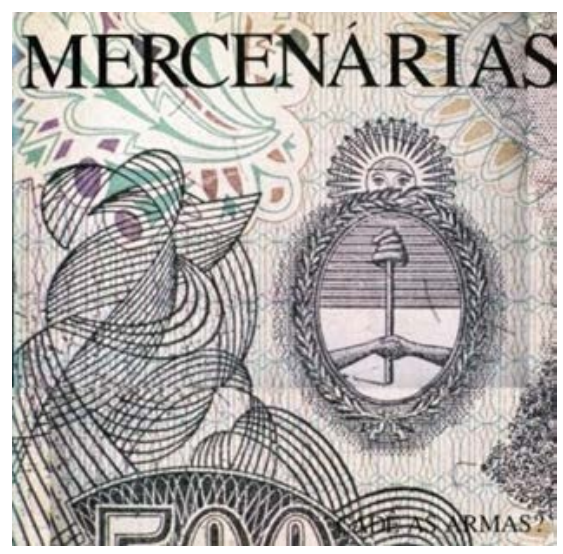

Fonte: Site Discogs. ${ }^{34}$

Disponivel em: https://www.discogs.com/pt_BR/Olho-Seco-Olho-Por-Olho/master/347215. Acesso em: 03 dez. 2020

32 Disponivel em: https://www.discogs.com/pt_BR/Olho-Seco-Olho-Por-Olho/master/347215. Acesso em: 03 dez. 2020

33 Disponivel em: https://www.discogs.com/pt_BR/Olho-Seco-Olho-Por-Olho/master/347215. Acesso em: 03 dez. 2020.

34 Disponivel em: https://www.discogs.com/pt_BR/Mercen\%C3\%A1rias-Cad\%C3\%AA-As-Armas/master/226029. Acesso em: 03 dez. 2020. 
É possível perceber a crítica ao consumo e ao dinheiro no primeiro LP das Mercenárias, única banda de maior projeção formada por mulheres no punk paulista. No disco Cadê as armas (Figura 18), de 1986, a imagem de capa é o fragmento de uma cédula de 500 pesos argentinos, porém, por estar ampliado, dificulta o entendimento à primeira vista. Apesar do tom crítico, compreendido na relação que há com as temáticas críticas das letras das músicas do grupo, esse projeto de design se mostra mais sutil e discreto do que os outros tendo em vista a leveza das linhas curvas da cédula.

O Garotos Podres foi a primeira banda do ABC Paulista a gravar um LP, lançado pelo selo independente Rocker, em 1985. O disco Mais podres do que nunca vendeu 50 mil cópias e foi relançado diversas vezes. A força do design está na relação entre capa e contracapa, parte do dispositivo, e depende da manipulação dessa embalagem. A capa (Figura 10) apresenta uma foto em tom sépia (que simula um tempo pregresso) de um bebê de cor branca e de fralda levantando uma mamadeira. O logotipo da banda ocupa o centro da imagem e é feito da colagem de letras de bordas rasgadas e com as duas letras "S" invertidas. Na contracapa (Figura 19), com a lista de músicas e outras informações do lado esquerdo, observa-se a foto também em preto e branco de uma criança negra magérrima, pobre, faminta com expressão de dor. A relação figurativa de contraste e tensão entre capa e contracapa, que se percebe pelo manuseio, traduz a postura crítica contra a miséria gerada pelo sistema e contra a elite branca e privilegiada, com destaque na capa, em contraste com os miseráveis, as minorias e os negros, que ocupam a margem, a contracapa. Tal relação crítica também se percebe na letra da música Papai Noel, velho batuta, na qual o personagem natalino presenteia os ricos e não os miseráveis.
Figura 19 - Mais podres do que nunca - contracapa (1985)

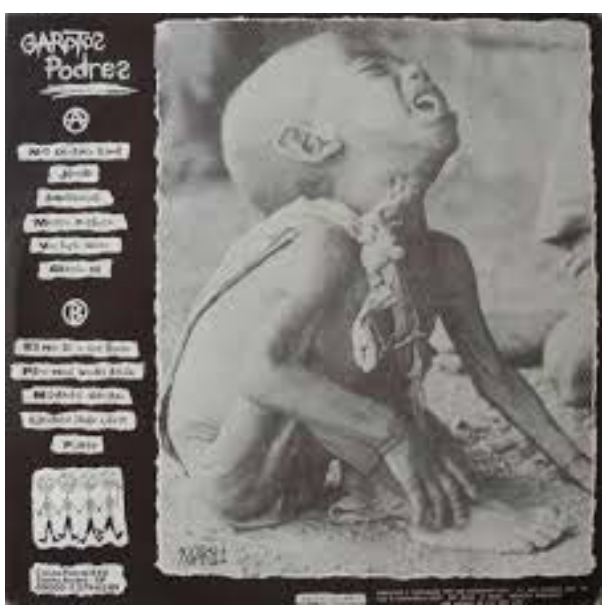

Fonte: Site Discogs. ${ }^{35}$

Da banda R.D.P., dois LPs podem ser destacados, ambos usando como técnica o desenho em cores. Na capa de Brasil (Figura 20), de 1989, um campo de futebol em perspectiva com um jogador pobre, descalço e desdentado é rodeado por outros desenhos em preto e branco com cenas de uma floresta em chamas, violência policial, padres introduzindo cruzes no ânus de indígenas, favelas, homens de terno matando um negro, entre outros. Tais desenhos ilustram, uma a uma, as músicas gravadas no disco e demonstram aspectos de violência, destruição e marginalidade contidos nelas, no ethos do movimento e na visualidade punk.

Figura 20 - Brasil - capa (1989)

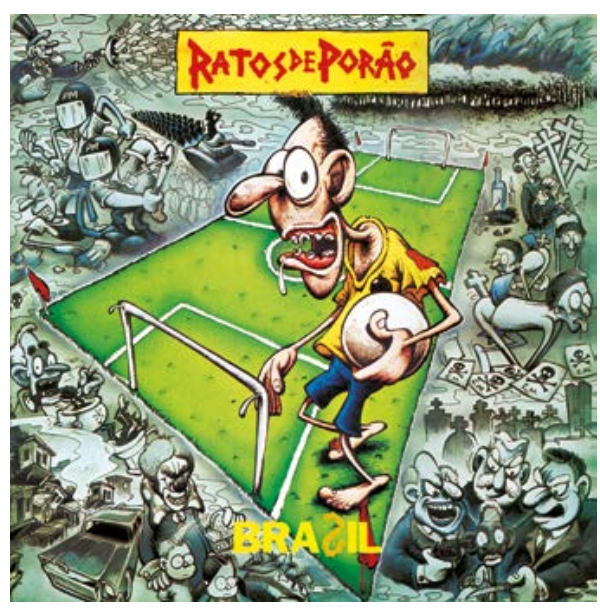

Fonte: Site Discogs. ${ }^{36}$

\footnotetext{
Disponivel em: https://www.discogs.com/pt_BR/Garotos-Podres-Mais-Podres-Do-Que-Nunca/release/4174117. Acesso em: 02 dez. 2020 Disponivel em: https://www.discogs.com/pt_BR/Ratos-De-Por\%C3\%A30-Brasil/master/54261. Acesso em: 03 dez. 2020
} 
Figura 21 - Anarkophobia - capa (1990)

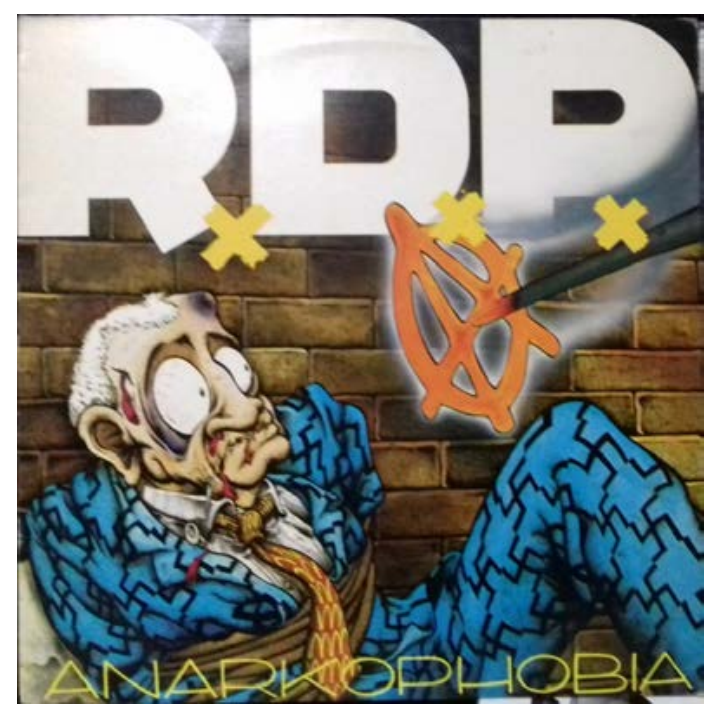

Fonte: Site Discogs. ${ }^{37}$

Já em Anarkophobia (Figura 21), de 1990, a capa traz o desenho de um homem amarrado de terno e gravata representando um capitalista, olhos arregalados de pavor, prestes e ser marcado com ferro em brasa com o símbolo do anarquismo, dando sentido ao título do disco e à música homônima. As riscas do terno são suásticas emendadas e, na gravata, a estampa é feita do logotipo de uma famosa rede de fast food. Em ambas as capas, os desenhos constroem representações das posturas criticas e políticas da banda, exatamente numa época em que o pais passava pela experiência do governo de perfil neoliberal do então presidente Fernando Collor de Mello.

Por fim, um forte posicionamento contra a destruição do meio ambiente pelo sistema capitalista está na capa de Verde, não devaste! (Figura 22), do Cólera, de 1989. A capa desenha em cores um mundo inóspito, seco, sem árvores, com animais mortos e um homem de máscara e tubo de oxigênio com um galho verde de árvore na mão. $O$ sol amarelo e o céu avermelhado aumentam a temperatura da cena. Já na contracapa (Figura 23), um desenho em preto e branco mostra a devastação da vegetação e dos rios feita pela poluição do mundo urbano industrial e capitalista figurado no horizonte da cena. A arte da capa traduz as temáticas das letras das músicas Bombeiro, Presidio Zoo, Don't Wast it! e Verde, que revelam preocupação com o futuro da fauna e da flora com o avanço exacerbado do capitalismo e da ganância humana esgotando recursos naturais em nome do progresso e do lucro.

Figura 22 - Verde, não devaste - capa (1989)

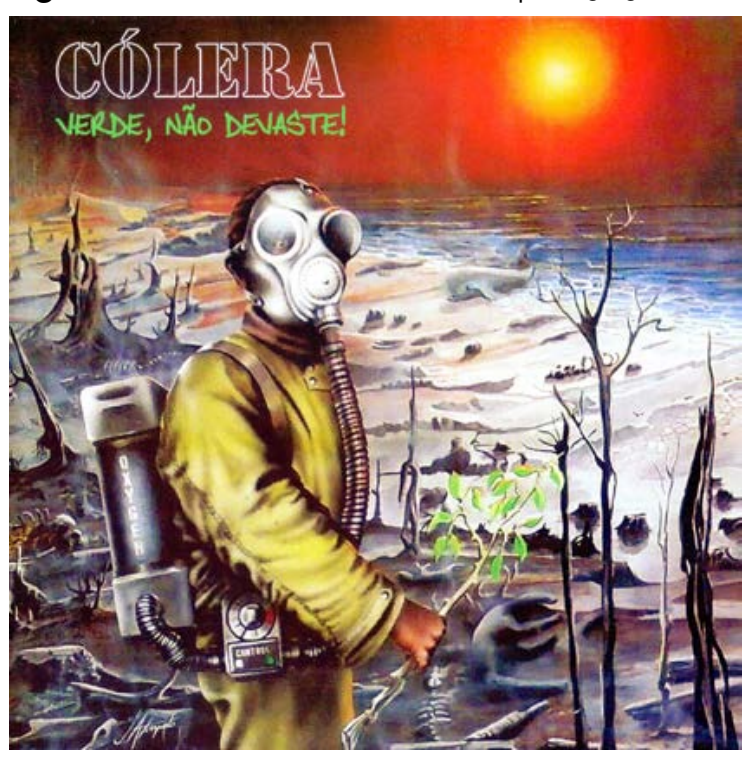

Fonte: Site Discogs. ${ }^{38}$

Figura 23 - Verde, não devaste - contracapa (1989)

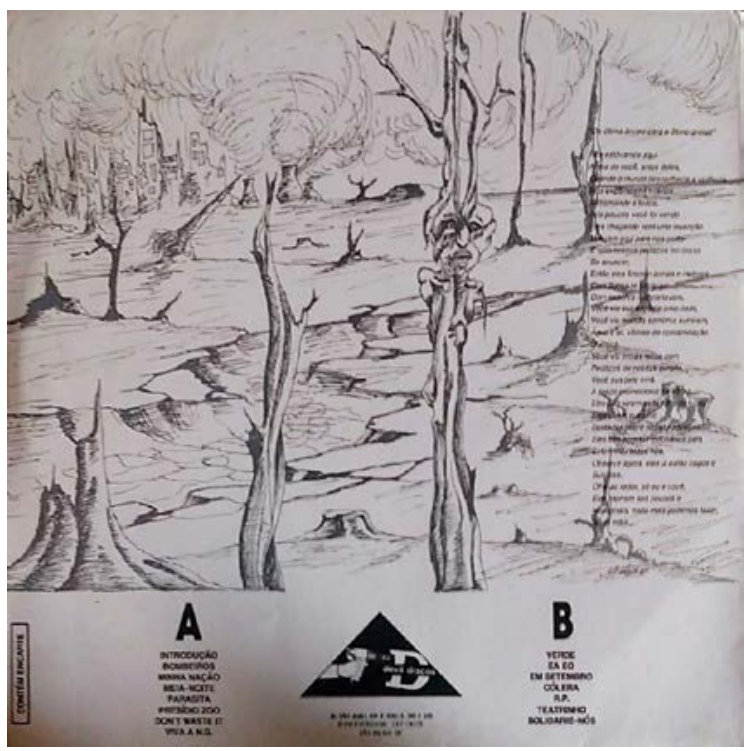

Fonte: Site Discogs. ${ }^{39}$

37 Disponivel em: https://www.discogs.com/pt_BR/RxDxPx-Anarkophobia/master/192852. Acesso em: 03 dez. 2020

38 Disponivel em: https://www.discogs.com/pt_BR/C\%C3\%B3lera-Verde-N\%C3\%A3o-Devaste/master/477615. Acesso em: 03 dez. 2020

39 Disponivel em: https://www.discogs.com/pt_BR/C\%C3\%B3lera-Verde-N\%C3\%A30-Devaste/master/477615. Acesso em: 03 dez. 2020. 


\section{Considerações finais}

A categorização, descrição e análise das capas de três coletâneas e de 23 discos de sete grupos punk de São Paulo e do ABC paulista mostram alguns aspectos singulares da imagética do movimento. Como muitas bandas se originaram na periferia, formadas por jovens com limitações financeiras, a lógica do "faça você mesmo" resultou em produções gráficas amadoras. No entanto, longe de serem menosprezados, esses projetos de design - muitos feitos pelos próprios músicos ou seus amigos - cumpriram o propósito de representar visualmente o gênero em questão para um público particular, cujo repertório estético correspondia aos campos formal e semântico partilhados pelas músicas e pela estética punk. Composições visuais desequilibradas, colagens desalinhadas, fotos rasgadas, lettering irregular, contrastes de todo tipo, desenhos de traços grosseiros e desajeitados, cores escuras ou quentes, acabamento pouco trabalhado, entre outros aspectos presentes nas capas, foram índices visuais e gráficos da música punk e de outros textos de seu entorno simbólico para um grupo de jovens críticos da ordem social capitalista na qual viviam na década de 1980 e início da de 1990.

Por mais que suas criticas soassem estéreis e limitadas, a violência das proposições e a criatividade visual foram encampadas pelos produtores das músicas e dos discos. Os elementos que indicam violência, grosseria, acabamento rudimentar, abjeção, tensão e desequilibrio foram indices presentes nas capas e ajudaram a construir a estética punk, junto de roupas, cabelos, fanzines, comportamento e músicas.

Como texto da cultura (LOTMAN, 1996), a capa mobiliza, por meio da linguagem visual e de sua constituição enquanto objeto estético, séries de relações com outros textos que orbitam as linguagens do punk. Mais que embalagem, a capa pode ser pensada como objeto autônomo que tece, na sua lógica semiótica, além de sua função mercadológica, outras articulações estéticas, temáticas, ideológicas e culturais. O design punk (um "não design") não é mera superficialidade, mas um microcosmo que dá sentido e corrobora a contundência das proposições em sua crueza plástica e objetividade semântica.

Daí pensarmos a capa de disco como um dos elementos mediadores simbólicos da produção e do consumo, objeto manuseável que reconstrói parte dos sentidos da música e do movimento cultural em questão por meio das imagens. Privilegiado por passar de mão em mão, por ser alvo de desejos e gostos, por acondicionar o disco que se quer ter e ouvir com prazer (REZENDE, 2006), por auxiliar na construção da representação estética e política do punk (HALL, 2016), tal espaço simbólico é referência no processo de negociação de gostos, de novos padrões e estéticas dentro do consumo jovem na sociedade.

Não à toa, tais padrões serão encampados, com certas acomodações, pela indústria fonográfica na década de 1980 nos discos de bandas de maior sucesso comercial, como Titãs, Legião Urbana, Ira, 365, entre outras que surgiram, em alguma medida, influenciadas pelo punk em suas derivações.

\section{Referências}

ALLEYNE, M. After the Storm: Hipgnosis, Storm Thorgerson, and the rock album cover. Rock Music Studies, Tennessee, v. 1, n. 3, p. 251-267, jul. 2014. Disponível em: https://www.researchgate.net/publication/271757849. After_the_Storm_Hipgnosis_Storm_Thorgerson_and_ the_Rock_Album_Cover. https://doi.org/10.1080/194 01159.2014.94.9553

AUMONT, J. A imagem. Campinas: Papirus, 1993.

BARCINSKI, A. João Gordo: viva la vida tosca. Rio de Janeiro: DarkSide Books, 2016

BIVAR, A. O que é punk. 4. ed. São Paulo: Brasiliense, 1988.

BORGES, L. F. R. Revista Pop e suas páginas coloridas: consumo e estética. Revista ECO-Pós, Rio de Janeiro, RJ, v. 8, n. 1, p. 86-99, jan./jul. 2005. Disponivel: https:// revistas.ufr.j.br/index.php/eco_pos/article/view/1097.

CARDOSO, R. Design para um mundo complexo. São Paulo: Ubu, 2016

DE VILLE, N. Album: style and image in sleeve design. London: Mitchell Beazley, 2003.

DONDIS, D. A. Sintaxe da linguagem visual. 2. ed. São Paulo: Martins Fontes, 2003

GOZZI, R.; BELINTANI, D. Kid Vinil: um herói do Brasil. São Bernardo do Campo: Edições Ideal, 2015. 
HALL, S. Cultura e representação. Rio de Janeiro: Apicuri/ PUC-Rio, 2016.

INGLIS, I. "Nothing you can see that isn't shown": the album covers of the Beatles. Popular Music, London, v. 20, n. 1, p. 83-97, 2001. Disponivel em: https://www. jstor.org/stable/853696? seq=1. https://doi.org/10.1017/ $\underline{\text { So261143001001325 }}$

JONES, S.; SORGER, M. Covering music: a brief history and analysis of album cover design. Journal of Popular Music Studies, California, v. 11, n. 1, p. 68-102, 1999. Disponivel em: https://onlinelibrary.wiley.com/doi/ abs/10.1111/j.1533-1598.1999.tbo0004.x. https://doi. org/10.1111/j.1533-1598.1999.tbo0004.x

LOTMAN, I. La semiosfera I. Semiótica de la cultura y del texto. Madrid: Ediciones Cátedra, 1996.

MCNEIL, L.; MCCAIN, G. Mate-me por favor: uma história sem censura do punk - vol. II. Porto Alegre: L\&PM, 2004.

MELNICK, M. A.; MEYER, F. Na estrada com os Ramones. São Bernardo do Campo: Edições Ideal, 2013.

MESTRINER, F. Design de embalagem: curso avançado. São Paulo: Makron Books, 2002.

NASCIMENTO, C. T.; PAIVA, M. R. Meninos em fúria: e o som que mudou a música para sempre. Rio de Janeiro: Alfaguara, 2016.

NEGUS, K. Producing pop: culture and conflict in the popular music industry. Londres: Edward Arnold, 1992.

O'HARA, C. A filosofia do punk: mais do que barulho. São Paulo: Radical Livros, 2005.

REZENDE, André Neves de. Da Lapa para a capa: estudo intersemiótico das capas de discos de samba vinculadas à imagem do malandro. 2006. $111 \mathrm{f}$. Dissertação (Mestrado em Educação, Arte e História da Cultura). Universidade Presbiteriana Mackenzie (UPM), São Paulo, 2006.

RODRIGUES, J. L. C. Tinindo, trincando: o design gráfico no tempo do desbunde. Conexão - Comunicação e Cultura, Caxias do Sul, RS, v. 5, n. 10. p. 72-102, jul./dez. 2006. Disponivel em: http://Www.ucs.br/etc/revistas/ index.php/conexao/article/view/217.

SASTRE, R. M.; MARTEL, M. Do vinil ao MP3: análise evolutiva das embalagens de discos no Brasil. Arcos Design, Rio de Janeiro, RJ, v. 9, n. 1, p. 121-136, 2016. Disponivel em: https://www.e-publicacoes.uerj.br/ index.php/arcosdesign/article/view/13586. https:// doi.org/10.12957/arcosdesign.2016.13586

VARGAS, Herom; BRUCK, Mozahir S. Memória visual e representação do rock e da jovem guarda nas capas de discos LP (1959-1970). E-Compós, São Bernardo do Campo, SP, v. 23, p. 1-26, 2020. https://doi. org/10.30962/ec.2007

VICENTE, E. Da vitrola ao iPod - uma história da indústria fonográfica no Brasil. São Paulo: Alameda, 2014.

\section{Audiovisual}

BOTINADA: A origem do Punk no Brasil. Direção: Gastão Moreira. São Paulo: Toro Company Productions, 2006. Documentário (76 min), son., cor. Disponivel em: https:// www.youtube.com/watch?V=22lSR-04ng8 Acesso em: 7 jun. 2019.

GUIDABLE: a verdadeira história do Ratos de Porão. Direção: Fernando Rick e Marcelo Appezzato, 2008. São Paulo: Black Vomit, 2008. Documentário (121 min), son., cor. Disponivel em: https://www.youtube.com/ watch? v=DDHICywnonA. Acesso em: 7 jun. 2019.

\section{Herom Vargas}

Doutor em Comunicação e Semiótica pela Pontifícia Universidade Católica de São Paulo (PUC-SP), em São Paulo, SP, Brasil; professor do Programa de Pós-Graduação em Comunicação Social (PósCom) da Universidade Metodista de São Paulo (UMESP), em São Bernardo do Campo, SP, Brasil.

\section{Renan Marchuesine de Quadros Souza}

Doutorando em Comunicação pela Universidade Metodista de São Paulo (UMESP), em São Bernardo do Campo, SP, Brasil.

\section{Endereço para correspondência}

Herom Vargas Silva

Universidade Metodista de São Paulo

Programa de Pós-graduação em Comunicação Social

Rua Alfeu Tavares, 149, prédio Capa

Rudge Ramos, 09641-000

São Bernardo do Campo, SP, Brasil

Renan Marchuesine de Quadros Souza

Rua Presidente Delfim Moreira, 220

Parque São Vicente, 09371-390

Mauá, SP, Brasil 